\title{
Do incretins improve endothelial function?
}

\author{
Jun-ichi Oyama ${ }^{1 *}$, Yukihito Higashi ${ }^{2}$ and Koichi Node ${ }^{1}$
}

\begin{abstract}
An impaired endothelial function has been recognized in the early stage of atherosclerosis, and is a major factor affecting the future development of cardiovascular events. Type 2 diabetes mellitus (T2DM) is widely prevalent, and is one of the most important risk factors for cardiovascular disease. T2DM is associated with increases in both morbidity and mortality, particularly from cardiovascular disease.

New therapies based on the incretin hormone and its actions are now becoming widely used, and appear to offer advantages over conventional therapies by keeping the body weight steady and limiting hypoglycemia, while also achieving attractive glycemic control. However, there is little data available about the effects of incretins on the cardiovascular system.

This review will focus on the effects of incretin therapies, including glucagon-like peptide-1 (GLP-1) analogs and dipeptidyl peptidase (DPP)-4 inhibitors, on the endothelial function, and will discuss the potential mechanisms underlying these effects.
\end{abstract}

Keywords: Incretin, GLP-1, DPP-4 inhibitor, Endothelial function, Diabetes mellitus type 2

\section{Introduction}

Type 2 diabetes (T2DM) is one of the most important risk factors for the development of cardiovascular disease (CVD) because it promotes systemic atherosclerosis and lifestyle-associated diseases. Recently, increasing evidence has revealed that impaired endothelial function leads to future cardiovascular events, including those in patients with T2DM. Endothelial dysfunction is an early feature of atherosclerosis that is characterized by a reduction of the bioavailability of vasodilators, particularly nitric oxide (NO) [1]. This condition is seen in various clinical populations, including patients with T2DM. The measurement of endothelial function as indicated by the flow-mediated dilation (FMD) via ultrasound has been established as a reliable non-invasive measurement of the endothelial function [2] and has been shown to correlate with the findings of more invasive testing of the endothelial function [3]. Numerous interventions that improve cardiovascular risk factors and reduce cardiovascular morbidity and mortality have been shown to increase the brachial artery reactivity measured by FMD, thus improving the endothelial function [4].

\footnotetext{
* Correspondence: junoyama@cc.saga-u.ac.jp

'Department of Cardiovascular Medicine, Saga University, 5-1-1 Nabeshima, Saga 849-8501, Japan

Full list of author information is available at the end of the article
}

Incretin hormones depend on the level of blood glucose to stimulate insulin. Recently, increasing evidence has suggested that glucagon-like peptide-1 (GLP-1)-related therapy has potent pleiotropic benefits on cardiovascular risk factors, beyondthe glycemic control. This review focuses on the theoretical and practical effects of incretin-related therapy on endothelial function, and describes the possible mechanism(s) of action.

\section{Biology of incretin hormones}

Incretin hormones are secreted from the gastrointestinal tract in response to food intake and have several systemic effects, including the glucose-dependent stimulation of insulin secretion by pancreatic beta-cells. Two incretins have been identified: GLP-1, derived from the L-cells of the distal small intestine and large bowel, and glucose-dependent insulinotropic polypeptide (GIP), derived from the K-cells of the proximal small intestine. GLP-1 and GIP are glucose-lowering agents that can interfere with postprandial hyperglycemia, which has been demonstrated to be associated with cardiovascular complications. GLP-1 is secreted primarily in two forms, GLP-1-(7-37) and GLP-1-(7-36)NH(2), both of which bind to a specific GLP-1 receptor (GLP-1R) on the pancreatic $\beta$-cell and augment glucose-stimulated insulin secretion. These peptides arise from the selective cleavage 
of the proglucagon molecule. GLP-1(7-36) amide is abundant in the circulation after meals and stimulates insulin secretion by interacting with GLP-1R on pancreatic $\beta$-cells. Activation of GLP-1R on $\beta$-cells leads to rapid increases in levels of cAMP and intracellular calcium followed by insulin exocytosis in a glucose-dependent manner [5]. GLP-1R, a $G$ protein-coupled receptor, has been detected in the nervous system, heart, vascular smooth muscle cells, endothelial cells, monocytes and macrophages as well as the gastrointestinal tract [6] (Figure 1).

The enzyme dipeptidyl peptidase (DPP)-4, also known as adenosine deaminase complexing protein 2, degrades GLP-1 to inactive GLP-1(9-36), and DPP-4 inhibitors bind to DPP-4 to prevent the breakdown of GLP-1 and GIP [7], thus increasing the half-life and bioavailability of active incretins, and enhancing their physiological effects. GLP-1(7-36) amide has been widely studied for its role as an active incretin and is referred to as GLP-1, unless otherwise specified. GLP-1(9-36) is thought to be an inactive metabolite due to its 1,000-fold lower affinity for GLP-1R and actions as a weak competitive antagonist without an incretin activity at pharmacological doses. However, GLP-1(9-36) may have potent effects on the cardiovascular system, similar to GLP-1(7-36) amide (Figure 2). Although it remains controversial, GLP1 may undergo multiple steps of enzymatic degradation by DPP-4 and neutral endopeptidase.

\section{Incretin-related drugs}

Nowadays, incretin-based therapies, including GLP-1R agonists and DPP-4 inhibitors, are becoming widely used as a new class of anti-diabetic drugs that exhibit different mechanisms of action from the conventional antidiabetic drugs (Table 1).

Exenatide, one of the GLP-1R agonists and incretin mimetics, bears a $50 \%$ amino acid homology to human
GLP-1 and it has a longer half-life in vivo, however, has its side effects including weight loss, nausea and vomiting. It must be injected twice daily. Liraglutide, a once-daily GLP-1 derivative, is also a long-acting GLP-1R agonist that shares $97 \%$ sequence identity to human GLP-1(7-37) and has a plasma half-life of 13 hours after subcutaneous administration in contrast to a short half-life of native GLP-1. DPP-4 inhibitors are also available with fewer side effects. ADA/EASD/IDF statement concerning the use of incretin therapy and pancreatic disease was reported in June, 2013. The strong relationship between incretin-therapy and pancretitis/pancreatic cancer was not recognized for now, however, we need to look at carefully.

Since DPP-4 inhibitors are associated with a lower incidence of hypoglycemia compared to conventional hypoglycemic drugs, they have been suggested to improve the mortality of patients with T2DM because they can enforce strict glycemic control without causing fatal hypoglycemia.

\section{Possible effects of incretins on vessels Incretin and endothelial cells (in vitro)}

GLP-1 was shown to attenuate the tumor necrosis factoralpha (TNF- $\alpha$ )-mediated induction of plasminogen activator inhibitor-1 expression [8] and inhibited advanced glycation end product (AGE)-induced upregulation of vascular cell adhesion molecule (VCAM)-1 in cultured human umbilical vein endothelial cells (HUVEC) [9]. It also upregulated the activity and protein expression of endothelial NO synthase (eNOS) in HUVEC through GLP-1Rdependent (GLP-1 (7-36)-related) and-independent (GLP1(9-36)-related) pathways [10]. GLP-1 prevented reactive oxygen species (ROS)-induced cell senescence through the activation of protein kinase A in HUVEC [11]. It also decreased high glucose-induced ROS production and decreased the apoptotic index, as well the levels of NADPH

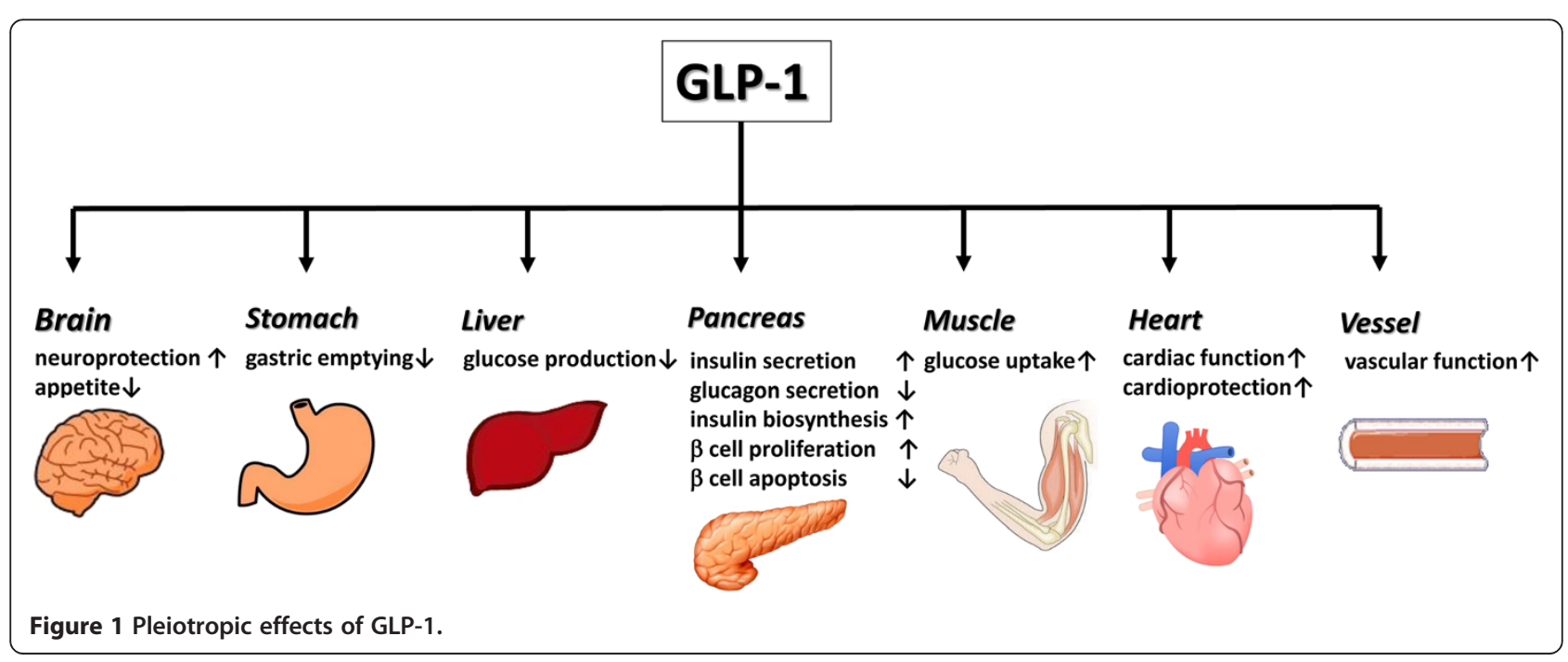




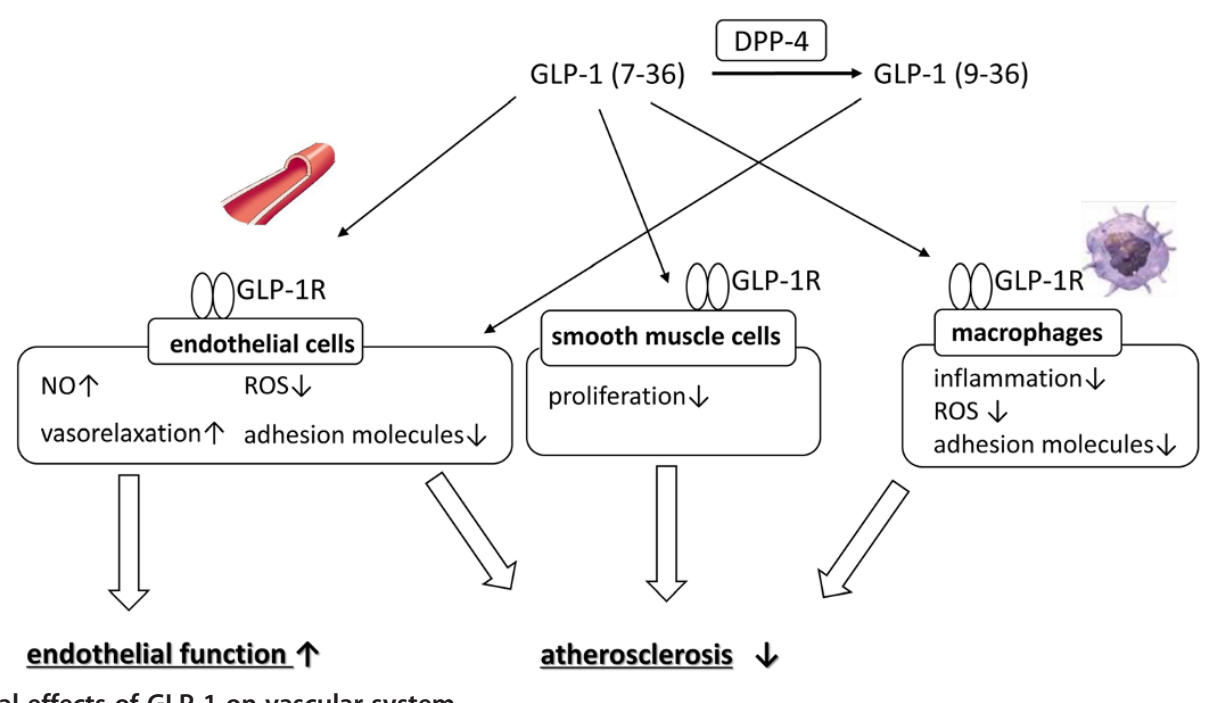

Figure 2 Beneficial effects of GLP-1 on vascular system.

oxidase and Rho-expression, with increases in the cAMP/ PKA activity in cardiac microvascular endothelial cells [12].

In turn, GLP-1 promoted angiogenesis in a dosedependent manner, which was decreased by Akt inhibitor IV, a PKC inhibitor and src inhibitor I in a 3D culture system where spherules of HUVEC were embedded in a collagen scaffold [13]. Moreover, GLP-1 restored the oxidized LDL-induced loss of cell viability in accordance with a significant decrease in intracellular NO activity. It suppressed the lipid peroxidation, restored the activities of endogenous antioxidants and decreased the levels of NO and cell apoptosis by preventing the upregulation of poly (ADP-ribose) polymerase-1/nitrotyrosine and inducible NO synthase protein in islet microvascular endothelial cells [14]. GLP-1 also improved the proliferation and differentiation of endothelial progenitor cells by upregulating vascular endothelial growth factor (VEGF) generation [15]. Exendin4, a GLP-1 agonist, stimulated the proliferation of human coronary artery endothelial cells through eNOS-, PKA- and PI3K/Akt-dependent pathways via the GLP-1 receptor [16]. Exendin-4 also and restored the eNOS-induced ROS production in response to lipotoxicity and protected against lipoapoptosis through PKA-PI3K/Akt-eNOS-p38 MAPK-JNK-dependent pathways via a GLP-1 receptordependent mechanism [17]. Liraglutide, another GLP-1 analog, prevented the onset of high glucose-induced endoplasmic reticulum stress in HUVEC [18] and inhibited TNF- $\alpha$-induced intracellular adhesion molecule (ICAM)1 and VCAM-1 expression, and these effects were dependent on the GLP-1R [19]. Moreover, we also demonstrated that liraglutide attenuated TNF- $\alpha$-induced ROS production and increased oxidative stress, and that it increased the expression of anti-oxidant enzymes, including superoxide dismutase-1 and -2, in HUVEC [20].

As DPP-4 inhibitor maintain the plasma level of active GLP-1, sitagliptin augments the protective effects of GLP-

Table 1 Features of incretin-related therapy

\begin{tabular}{|c|c|c|c|c|}
\hline & Administration & Clearance & & effects \\
\hline GLP-1R agonist & Subctaneous & & Weight loss & Gastrointestinal tract (GIT) \\
\hline Exenatide & Twice a day, once a week & Renal & + & $++/ \pm^{*}$ \\
\hline Liraglutide & Once a day & Extrarenal & + & + \\
\hline DPP-4 inhibitor & Oral & & $\rightarrow$ & $\rightarrow$ \\
\hline Sitagliptin & Once a day & Renal & $\rightarrow$ & $\rightarrow$ \\
\hline Vildagliptin & Twice a day & Renal & $\rightarrow$ & $\rightarrow$ \\
\hline Saxagliptin & Once a day & Renal & $\rightarrow$ & $\rightarrow$ \\
\hline Linagliptin & Once a day & Extrarenal & $\rightarrow$ & $\rightarrow$ \\
\hline Anagliptin & Twice a day & Renal & $\rightarrow$ & $\rightarrow$ \\
\hline Teneligliptin & Once a day & Extrarenal > renal & $\rightarrow$ & $\rightarrow$ \\
\hline Alogliptin & Once a day & Renal & $\rightarrow$ & $\rightarrow$ \\
\hline
\end{tabular}

*Exenatide once weekly has less side effects of GIT as compared to linagrutide. 
1 on the eNOS mRNA level in AGEs-exposed HUVEC with suppressing the receptor for AGE (RAGE) expression and the subsequent ROS generation [21]. Alogliptin induced vascular relaxation via $\mathrm{NO}$ and endothelialderived hyperpolarizing factor-mediated mechanisms, and increased the NO production with increased eNOS phosphorylation in HUVEC, which was not inhibited by GLP$1 \mathrm{R}$ antagonist, exendin 9-39, although NO inhibition or endothelial denudation decreased relaxation response. [22]. Therefore, this relaxation by alogliptin may be mediated by GLP-1R-independent mechanisms. Since decreasing the oxidative stress results in a restoration of the eNOS function, all of these phenomena, including the decreased ROS production and increased eNOS expression, in addition to the endothelial repair and promotion of angiogenesis, lead to an amelioration of the endothelial function.

\section{The in vivo or ex vivo endothelial function}

Exendin-4 significantly increased the NO level, improved the endothelium-dependent vasodilatation and reduced the expression of NF- $\mathrm{KB}$ in the aortas isolated from obese rats. This was demonstrated to occur through the cAMP or AMPK-eNOS pathways [23]. Exendin-4 also inhibited the monocyte adhesion and attenuated the formation of atherosclerotic lesions in apolipoprotein Edeficient (ApoE-/-) mice [24]. Liraglutide improved the endothelial function via GLP-1R, increased the eNOS level and reduced the ICAM-1 expression in the aortic endothelium in mice [19]. Liraglutide also inhibited the progression of atherosclerotic plaques, and improve the plaque stability in ApoE-/- mice [25], although the extent of endothelial vasodilatation induced by acetylcholine $(\mathrm{ACh})$ was not changed. Sitagliptin protected the endothelial function of the renal artery in spontaneously hypertensive rats, and exenatide ameliorated the endothelial dysfunction in the renal arteries from hypertensive patients in an ex vivo study [26]. On the other hand, Nathanson et al. reported that the endothelial dysfunction induced by triglycerides was not restored by exendin- 4 treatment in rat conduit arteries ex vivo [27].

\section{Other possible effects of Incretins on the endothelium, possible effects of incretins on vessels and clinical data Lowering blood pressure}

In recent studies, DPP-4 inhibitors and GLP-1 analogs were recognized to lower the systemic blood pressure $[28,29]$. One of the possible mechanisms underlying this effect is explained by the extraction of $\mathrm{Na}^{+}$, because GLP1 induces natriuresis in humans [30]. Another possibility is the increase in the activity of eNOS described above, because eNOS-knockout mice [31] and the administration of a NOS inhibitor both led to increased blood pressure [32]. Moreover, Kim et al. reported that GLP-1R activation promotes the secretion of atrial natriuretic peptide and a reduction of blood pressure [33].

As DPP-4 cleaves a wide variety of substrates, including stromal cell-derived factor-1 (SDF-1) alpha, which stimulates the bone marrow mobilization of endothelial progenitor cells (EPC) and brain natriuretic peptide (1-32), which is the active form [34], DPP-4 inhibition may repair endothelial cells and improve the cardiac function, thus resulting in an indirect improvement of the endothelial function.

\section{Lipid metabolism}

DPP-4 inhibitors reduced the serum levels of cholesterol and triglycerides in mice and humans [28,35]. GLP-1 also decreased the lipid absorption in vivo [36]. Therefore, incretins may improve the endothelial function by correcting the lipid metabolism. However, exendin-4 did not affect the levels of cholesterol and triglycerides in mice [35].

\section{Clinical data}

Table 2 lists the effects of GLP-1 and GLP-1-related drugs on the endothelial function. Although GLP-1 enhanced the endothelium-dependent and -independent responses to ACh and sodium nitroprusside (SNP) during infusion of insuline, but not during infusion of saline in patients with metabolic syndrome. Furthermore, no changes in the vasodilator reactivity in response to $\mathrm{ACh}$ and SNP were seen after GLP-1 was added to insulin and vitamin $C$ or after GLP-1(9-36) was given during hyperinsulinemia [37]. Kelly et al. demonstrated that exendin-4 did not improve the responses of peripheral arterial tonometry compared to metformin in patients with impaired glucose tolerance [38]. In addition, exendin- 4 and liraglutide could not improve the FMD responses in obese patients with T2DM [39]. Surprisingly, sitagliptin and alogliptin actually led to a deterioration in the FMD responses in patients with T2DM [40]. Since the DPP-4 inhibitors inhibited DPP-4 activity and increased the level of GLP-1, in addition to lowering the glucose level, in this study, it is clear that the DPP-4 inhibitors worked efficiently. The authors suggested that GLP-1(9-36), a metabolite of GLP-1 cleaved by the DPP-4 inhibitor, was thought to be inactive, but possessed a vasodilatory effect ex vivo which was mediated by NO [6]. However, sitagliptin, alogliptin and vildagliptin also improved the endothelial function in other studies. Therefore, it is hard to simply conclude whether the discrepancy was due to the differences in the drugs or the inhibition of GLP-1 (9-36).

On the other hand, nine studies previously reported that the endothelial function was improved by using GLP-1 and GLP-1-related drugs [37,41-48]. This effect is still being debated, because all of these studies included a small number $(<50)$ of patients, and almost all were non-randomized trials. Therefore, a large-scaled randomized 
Table 2 Clinical evaluation of endothelial function

\begin{tabular}{|c|c|c|c|c|c|c|c|}
\hline Author & Subjects & $\mathbf{n}$ & Endothelial function & Medication & Control & Duration & Result \\
\hline Basu A et al. [41] & T2DM & 29 & Strain-gauged plethysmography & GLP-1 & Placebo & $240 \mathrm{~min}$ & Improved \\
\hline Kubota Y et al. [42] & T2DM & 40 & FMD & Sitagliptin & None & $12 \mathrm{w}$ & Improved \\
\hline Nystrom T et al. [43] & T2DM & 12 & FMD & GLP-1 & Saline & $115 \mathrm{~min}$ & Improved \\
\hline Koska J et al. [44] & T2DM & 28 & РAT & Exendin-4 & Saline & $210 \mathrm{~min}$ & Improved \\
\hline Noda Y et al. [45] & Healty volunteer & 10 & FMD & Alogliptin & Placebo & $1 \mathrm{w}$ & Improved \\
\hline van Poppel PC et al. [46] & T2DM & 16 & Strain-gauged plethysmography & Vildagliptin & Acarbose & $4 w$ & Improved \\
\hline Ceriello A et al. [47] & T2DM & 28 & FMD & GLP-1 & Saline & $2 \mathrm{~h}$ & Improved \\
\hline Irace C et al. [48] & T2DM & 20 & FMD & Exendin-4 & Glimepiride & $16 w$ & Improved \\
\hline Tesauro $M$ et al. [37] & Metabolic syndrome & $10(5 / 5)$ & Strain-gauged plethysmography & GLP-1 & Saline & $30 \mathrm{~min}$ & Improved (conditional) \\
\hline Kelly AS et al. [38] & IGT & 50 & PAT & Exendin-4 & Metformin & $6 \mathrm{~m}$ & No change \\
\hline Hopkins ND, et al. [39] & Obese T2DM & 11 & FMD & Exendin-4 $(n=9)$ Liragrutide $(n=2)$ & None & $6 \mathrm{~m}$ & No change \\
\hline Ayaori M et al. [40] & T2DM & $13 \sim 20,22$ & FMD & Sitagliptin/alogliptin & Voglibose & $6 w$ & Worsened \\
\hline
\end{tabular}

T2DM: type2 diabetes mellitus, GLP-1: glucagon-like peptide-1, FMD: flow-mediated dilation, IGT: impaired glucose tolerance, PAT: Peripheral arterial tonometry. 
trial will be necessary to clearly define the impact of these agents on the endothelial function.

We designed and are performing an ongoing multicenter randomized prospective study to evaluate the effects of DPP-4 inhibition on carotid atherosclerosis by measuring the carotid intima-media thickness (PROLOGUE trial: UMIN000004490). In this trial, the effects of a DPP-4 inhibitor on the FMD will be analyzed as part of a subgroup of the study. The result of this study may answer the questions remaining regarding the effects of DDP-4 inhibition.

\section{Do incretins improve the prognosis and mortality from cardiovascular disease?}

Recently, the results of cardiovascular safety trials of type 2 diabetes drugs, EXAMINE trial with alogliptin and SAVOR-TIMI 53 trial with saxagliptin, were reported $[49,50]$. These two studies found no effect on the risk of fatal or non-fatal cardiac events and no increases in the risk of pancreatitis or pancreatic cancer. The results were disappointing because the studies did not demonstrate any cardiovascular protective benefits of DPP-4 inhibitors. There are a few limitations. First, the followup period was too short to evaluate the incidence of cardiovascular events, because the effects of drugs in fighting pro-atherosclerotic processes in patients with T2DM requires more than 10 years. Second, the relatively small HbA1c-lowering effects of saxagliptin and alogliptin observed in both trials, averaging only 0.3 to 0.4 percentage points. It may influence the final results. Further subanalyses and other ongoing trials need to be waited.

We need to admonish against jumping illogically.

\section{Additional features and limitations}

The blood vessels modulate vascular tone and blood flow by constricting or relaxing in response to physical, neurological and chemical stimuli. Endothelial dysfunction is recognized as a major factor in the development of atherosclerosis and FMD is designated as an endotheliumdependent process that reflects the relaxation of a conduit artery (brachial, radial, and femoral) when exposed to increased blood flow and shear stress and recognized as useful tool for the assessment of endothelial function in different clinical and research populations. Recently FMD is recognized as an independent predictor of future cardiac events $[51,52]$.

It is a simple and widely available method, however, there are several caveats due to the potential technical variations [53], these include:

1) An acceptable reproducibility is a mean difference of $2 \%$ to $3 \%$ in the FMD over time. To measure the FMD precisely, 100 independent supervised scans and measurements are required according to a previous report.
2) At least 40 to 60 patients in a parallel-group study are needed because of the fluctuation of the data.

3) The diameters of small arteries at baseline appear to dilate more than those of larger arteries, and repeated measurements of the diameter at baseline must be the same. Therefore, the precise vessel diameters before and after reactive hyperemia (mean baseline and peak deflation diameters) have to be addressed in addition to the \% changes of the FMD.

4) In multicenter studies, the methods used for the measurement should be unified, and a core laboratory should be used to analyze the FMD data to minimize the variations among the different centers.

Measurement errors are present in all of the data because of the biological variations and methodological limitations described above. Therefore, the evaluations must be performed carefully and precisely. Guidelines for measuring the FMD have been published [53-55], and the Japanese Circulation Society will announce new guidelines in 2014. Therefore, it is necessary to recognize the limitations and the features of FMD and to measure the FMD as precisely as possible in compliance with the guidelines.

In addition to atherosclerosis, incretins may prevent myocardial ischemia-reperfusion (I/R) injury. Sitagliptin or vildagliptin for two weeks reduced infarct size after myocardial I/R injury through the GLP-1 receptor-PKA pathway, in a glucose-dependent manner in rat in ex vivo [56] In addition, exendin-4 could attenuate myocardial I/R injury which may be associated with inhibiting the expression of high mobility group box 1 in ra in vivo [57]. As myocardial ischemia-reperfusion is critical for the patients with coronary artery disease or acute coronary syndrome who underwent percutaneous coronary intervention, incretin-therapy may have beneficial effects beyond glycemic control.

Finally, we would like to add that this review is not a systematic review or meta-analysis based on the PRISMA guidelines [58].

\section{Conclusions}

Atherosclerosis and the subsequent cardiovascular disease are fatal, and early prevention of cardiovascular complications by ensuring strict glucose control is essential for patients with T2DM. The current findings add to a growing body of evidence that suggests that we might be entering a new era of cardiovascular diabetology with new anti-diabetic drugs for now. On the other hand, several investigations contradicted the beneficial effects of incretin on the vasculature. Therefore, as a next step, large-scaled randomized, prospective, clinical studies and their subanalyses will provide the evidence whether incretin therapy provide clinical benefits of vascular 
protection beyond glycemic control for patients with T2DM who are at risk of cardiovascular disease.

\section{Abbreviation}

T2DM: Type 2 diabetes mellitus; GLP-1: Glucagon-like peptide-1; GIP: Insulinotropic polypeptide; GLP-1R: GLP-1 receptor; DPP: Dipeptidyl peptidase; CVD: Cardiovascular disease; NO: Nitric oxide; FMD: Flow-mediated dilation; ROS: Reactive oxygen species; AGE: Advanced glycation end product; VCAM: Vascular cell adhesion molecule; HUVEC: Human umbilical vein endothelial cells; eNOS: Endothelial NO synthase; VEGF: Vascular endothelial growth factor; ICAM: Intercellular adhesion molecule; RAGE: The receptor for AGE; ApoE-/-: apolipoprotein E deficient; SDF: Stromal cellderived factor; ACh: Acetylcholine; SNP: Sodium nitroprusside.

\section{Competing interests}

The authors declare that they have no competing interests.

\section{Authors' contributions}

All authors contributed to conception and design, drafting the article, revising the article critically, and final approval of the version to be published.

\section{Author details}

'Department of Cardiovascular Medicine, Saga University, 5-1-1 Nabeshima, Saga 849-8501, Japan. ${ }^{2}$ Department of Cardiovascular Regeneration and Medicine, Research Institute for Radiation Biology and Medicine, Hiroshima University, Hiroshima, Japan.

Received: 28 December 2013 Accepted: 10 January 2014

Published: 15 January 2014

\section{References}

1. Lerman A, Burnett JC Jr: Intact and altered endothelium in regulation of vasomotion. Circulation 1992, 86:|l|-12-II-19.

2. Uehata A, Lieberman EH, Gerhard MD, Anderson TJ, Ganz P, Polak JF, Creager MA, Yeung AC: Noninvasive assessment of endothelium-dependent flow-mediated dilation of the brachial artery. Vasc Med 1997, 2:87-92.

3. Anderson TJ, Uehata A, Gerhard MD: Close relationship of endothelial function in the human coronary and peripheral circulations. J Am Coll Cardiol 1995, 26:1235-1241.

4. Celermajer D: Endothelial dysfunction: does it matter? Is it reversible? J Am Coll Cardiol 1997, 30:325-333.

5. Drucker DJ, Philippe J, Mojsov S, Chick WL, Habener JF: Glucagon-like peptide I stimulates insulin gene expression and increases cyclic AMP levels in a rat islet cell line. Proc Natl Acad Sci U S A 1987, 84:3434-3438.

6. Ban K, Noyan-Ashraf MH, Hoefer J, Bolz SS, Drucker DJ, Husain M: Cardioprotective and vasodilatory actions of glucagon-like peptide 1 receptor are mediated through both glucagon-like peptide 1 receptor-dependent and -independent pathways. Circulation 2008, 117:2340-2350.

7. Gallwitz B: Review of sitagliptin phosphate: a novel treatment for type 2 diabetes. Vasc Health Risk Manag 2007, 3:203-210.

8. Liu H, Hu Y, Simpson RW, Dear AE: Glucagon-like peptide-1 attenuates tumour necrosis factor-alpha-mediated induction of plasminogen activator inhibitor-1 expression. J Endocrinol 2008, 196:57-65.

9. Ishibashi Y, Matsui T, Takeuchi M, Yamagishi S: Glucagon-like peptide-1 (GLP-1) inhibits advanced glycation end product (AGE)-induced upregulation of VCAM-1 mRNA levels in endothelial cells by suppressing AGE receptor (RAGE) expression. Biochem Biophys Res Commun 2010, 391:1405-1408.

10. Ding L, Zhang J: Glucagon-like peptide-1 activates endothelial nitric oxide synthase in human umbilical vein endothelial cells. Acta Pharmacol $\sin 2012,33: 75-81$

11. Oeseburg $H$, de Boer RA, Buikema $H$, van der Harst $P$, van Gilst $W H$, Silljé $H H$ : Glucagon-like peptide 1 prevents reactive oxygen species-induced endothelial cell senescence through the activation of protein kinase A. Arterioscler Thromb Vasc Biol 2010, 30:1407-1414.

12. Wang D, Luo P, Wang Y, Li W, Wang C, Sun D, Zhang R, Su T, Ma X, Zeng C, Wang H, Ren J, Cao F: Glucagon-like peptide-1 protects against cardiac microvascular injury in diabetes via a CAMP/PKA/Rho-dependent mechanism. Diabetes 2013, 62:1697-1708.
13. Aronis KN, Chamberland JP, Mantzoros CS: GLP-1 promotes angiogenesis in human endothelial cells in a dose-dependent manner, through the Akt, Src and PKC pathways. Metabolism 2013, 62:1279-1286.

14. Liu FQ, Zhang XL, Gong L, Wang XP, Wang J, Hou XG, Sun Y, Qin WD, Wei SJ, Zhang Y, Chen L, Zhang MX: Glucagon-like peptide 1 protects microvascular endothelial cells by inactivating the PARP-1/iNOS/NO pathway. Mol Cell Endocrinol 2011, 339:25-33.

15. Xiao-Yun X, Zhao-Hui M, Ke C, Hong-Hui H, Yan-Hong X: Glucagon-like peptide-1 improves proliferation and differentiation of endothelial progenitor cells via upregulating VEGF generation. Med Sci Monit 2011, 17:BR35-BR41.

16. Erdogdu O, Nathanson D, Sjöholm A, Nyström T, Zhang Q: Exendin-4 stimulates proliferation of human coronary artery endothelial cells through eNOS-, PKA- and PI3K/Akt-dependent pathways and requires GLP-1 receptor. Mol Cell Endocrinol 2010, 325:26-35.

17. Erdogdu O, Eriksson L, Xu H, Sjöholm A, Zhang Q, Nyström T: Exendin-4 protects endothelial cells from lipoapoptosis by PKA, PI3K, eNOS, p38 MAPK, and JNK pathways. J Mol Endocrinol 2013, 50:229-241.

18. Schisano B, Harte AL, Lois K, Saravanan P, Al-Daghri N, Al-Attas O, Knudsen LB, McTernan PG, Ceriello A, Tripathi G: GLP-1 analogue, Liraglutide protects human umbilical vein endothelial cells against high glucose induced endoplasmic reticulum stress. Regul Pept 2012, 174:46-52.

19. Gaspari T, Liu H, Welungoda I, Hu Y, Widdop RE, Knudsen LB, Simpson RW, Dear AE: A GLP-1 receptor agonist liraglutide inhibits endothelial cell dysfunction and vascular adhesion molecule expression in an ApoE-/mouse model. Diab Vasc Dis Res 2011, 8:117-124.

20. Shiraki A, Oyama J, Komoda H, Asaka M, Komatsu A, Sakuma M, Kodama K, Sakamoto Y, Kotooka N, Hirase T, Node K: The glucagon-like peptide 1 analog liraglutide reduces TNF-a-induced oxidative stress and inflammation in endothelial cells. Atherosclerosis 2012, 221:375-382.

21. Ishibashi Y, Matsui T, Takeuchi M, Yamagishi S: Sitagliptin augments protective effects of GLP-1 against advanced glycation end product receptor axis in endothelial cells. Horm Metab Res 2011, 43:731-734.

22. Shah Z, Pineda C, Kampfrath T, Maiseyeu A, Ying Z, Racoma I, Deiuliis J, Xu X, Sun Q, Moffatt-Bruce S, Villamena F, Rajagopalan S: Acute DPP-4 inhibition modulates vascular tone through GLP-1 independent pathways. Vascul Pharmacol 2011, 55:2-9.

23. Han $L, Y u$ Y, Sun $X$, Wang B: Exendin-4 directly improves endothelial dysfunction in isolated aortas from obese rats through the CAMP or AMPK-eNOS pathways. Diabetes Res Clin Pract 2012, 97:453-460.

24. Arakawa M, Mita T, Azuma K, Ebato C, Goto H, Nomiyama T, Fujitani Y, Hirose T, Kawamori R, Watada H: Inhibition of monocyte adhesion to endothelial cells and attenuation of atherosclerotic lesion by a glucagon-like peptide-1 receptor agonist, exendin-4. Diabetes 2010, 59:1030-1037.

25. Gaspari T, Welungoda I, Widdop RE, Simpson RW, Dear AE: The GLP-1 receptor agonist liraglutide inhibits progression of vascular disease via effects on atherogenesis, plaque stability and endothelial function in an ApoE-/- mouse model. Diab Vasc Dis Res 2013, 10:353-360.

26. Liu L, Liu J, Wong WT, Tian XY, Lau CW, Wang YX, Xu G, Pu Y, Zhu Z, Xu A, Lam KS, Chen ZY, Ng CF, Yao X, Huang Y: Dipeptidyl peptidase 4 inhibitor sitagliptin protects endothelial function in hypertension through a glucagon-like peptide 1-dependent mechanism. Hypertension 2012, 60:833-841.

27. Nathanson D, Erdogdu O, Pernow J, Zhang Q, Nyström T: Endothelial dysfunction induced by triglycerides is not restored by exenatide in rat conduit arteries ex vivo. Regul Pept 2009, 157:8-13.

28. Sakamoto Y, Oyama J, Ikeda H, Kuroki S, Gondo S, Iwamoto T, Uchida Y, Kodama K, Hiwatashi A, Shimomura M, Taguchi I, Inoue T, Node K, S-DOG investigators: Effects of sitagliptin beyond glycemic control: focus on quality of life. Cardiol Diabetol 2013, 12:35.

29. Scheen AJ: Cardiovascular effects of gliptins. Nat Rev Cardiol 2013, 10:73-84

30. Gutzwiller JP, Tschopp S, Bock A, Zehnder CE, Huber AR, Kreyenbuehl M, Gutmann H, Drewe J, Henzen C, Goeke B, Beglinger C: Glucagon-like peptide 1 induces natriuresis in healthy subjects and in insulin-resistant obese men. J Clin Endocrinol Metab 2004, 89:3055-3061.

31. Huang PL, Huang Z, Mashimo H, Block KD, Moskowitz MA, Bevan JA, Fishman MC: Hypertension in mice lacking the gene for endothelial nitric oxide synthase. Nature 1995, 377:239-242.

32. Rees DD, Palmer RM, Moncada S: Role of endothelium-derived nitric oxide in the regulation of blood pressure. Proc Natl Acad Sci U S A 1989, 86:3375-3378 
33. Kim M, Platt MJ, Shibasaki T, Quaggin SE, Backx PH, Seino S, Simpson JA, Drucker DJ: GLP-1 receptor activation and Epac2 link atrial natriuretic peptide secretion to control of blood pressure. Nat Med 2013, 19:567-575.

34. Vanderheyden M, Bartunek J, Goethals M, Verstreken S, Lambeir AM, De Meester I, Scharpé S: Dipeptidyl-peptidase IV and B-type natriuretic peptide. From bench to bedside. Clin Chem Lab Med 2009, 47:248-252.

35. Flock G, Baggio LL, Longuet C, Drucker DJ: Incretin receptors for glucagonlike peptide 1 and glucose-dependent insulinotropic polypeptide are essential for the sustained metabolic actions of vildagliptin in mice. Diabetes 2007, 56:3006-3013.

36. Qin X, Shen H, Liu M, Yang Q, Zheng S, Sabo M, D'Alessio DA, Tso P: GLP-1 reduces intestinal lymph flow, triglyceride absorption, and apolipoprotein production in rats. Am J Physiol Gastrointest Liver Physiol 2005, 288:G943-G949.

37. Tesauro M, Schinzari F, Adamo A, Rovella V, Martini F, Mores N, Barini A Pitocco D, Ghirlanda G, Lauro D, Campia U, Cardillo C: Effects of GLP-1 on forearm vasodilator function and glucose disposal during hyperinsulinemia in the metabolic syndrome. Diabetes Care 2013, 36:683-689.

38. Kelly AS, Bergenstal RM, Gonzalez-Campoy JM, Bank AJ, Katz H: Effects of exenatide vs. metformin on endothelial function in obese patients with pre-diabetes: a randomized trial. Cardiovasc Diabetol 2012, 11:64.

39. Hopkins ND, Cuthbertson DJ, Kemp GJ, Pugh C, Green DJ, Cable NT, Jones $\mathrm{H}$ : Effects of 6 months glucagon-like peptide-1 receptor agonist treatment on endothelial function in type 2 diabetes mellitus patients. Diabetes Obes Metab 2013, 15:770-773.

40. Ayaori M, Iwakami N, Uto-Kondo H, Sato H, Sasaki M, Komatsu T, lizuka M, Takiguchi S, Yakushiji E, Nakaya K, Yogo M, Ogura M, Takase B, Murakami T, Ikewaki K: Dipeptidyl peptidase-4 inhibitors attenuate endothelial function as evaluated by flow-mediated vasodilatation in type 2 diabetic patients. J Am Heart Assoc 2013, 2:e003277.

41. Basu A, Charkoudian N, Schrage W, Rizza RA, Basu R, Joyner MJ: Beneficial effects of GLP-1 on endothelial function in humans: dampening by glyburide but not by glimepiride. Am J Physiol Endocrinol Metab 2007, 293:E1289-E1295.

42. Kubota Y, Miyamoto M, Takagi G, Ikeda T, Kirinoki-Ichikawa S, Tanaka K, Mizuno K: The dipeptidyl peptidase-4 inhibitor sitagliptin improves vascular endothelial function in type 2 diabetes. J Korean Med Sci 2012, 27:1364-1370.

43. Nyström T, Gutniak MK, Zhang Q, Zhang F, Holst JJ, Ahrén B, Sjöholm A: Effects of glucagon-like peptide- 1 on endothelial function in type 2 diabetes patients with stable coronary artery disease. Am J Physiol Endocrinol Metab 2004, 287:E1209-E1215.

44. Koska J, Schwartz EA, Mullin MP, Schwenke DC, Reaven PD: Improvement of postprandial endothelial function after a single dose of exenatide in individuals with impaired glucose tolerance and recent-onset type 2 diabetes. Diabetes Care 2010, 33:1028-1030.

45. Noda Y, Miyoshi T, Oe H, Ohno Y, Nakamura K, Toh N, Kohno K, Morita H, Kusano K, Ito H: Alogliptin ameliorates postprandial lipemia and postprandial endothelial dysfunction in non- diabetic subjects: a preliminary report. Cardiovasc Diabetol 2013, 12:8.

46. van Poppel PC, Netea MG, Smits P, Tack CJ: Vildagliptin improves endothelium-dependent vasodilatation in type 2 diabetes. Diabetes Care 2011, 34:2072-2077

47. Ceriello A, Esposito K, Testa R, Bonfigli AR, Marra M, Giugliano D: The possible protective role of glucagon-like peptide 1 on endothelium during the meal and evidence for an "endothelial resistance" to glucagon-like peptide 1 in diabetes. Diabetes Care 2011, 34:697-702.

48. Irace C, De Luca S, Shehaj E, Carallo C, Loprete A, Scavelli F, Gnasso A: Exenatide improves endothelial function assessed by flow mediated dilation technique in subjects with type 2 diabetes: results from an observational research. Diab Vasc Dis Res 2013, 10:72-77.

49. White WB, Cannon CP, Heller SR, Nissen SE, Bergenstal RM, Bakris GL, Perez AT, Fleck PR, Mehta CR, Kupfer S, Wilson C, Cushman WC, Zannad F, EXAMINE Investigators: Alogliptin after acute coronary syndrome in patients with type 2 diabetes. N Engl J Med 2013, 369:1327-1335.

50. Scirica BM, Bhatt DL, Braunwald E, Steg PG, Davidson J, Hirshberg B, Ohman P, Frederich R, Wiviott SD, Hoffman EB, Cavender MA, Udell JA, Desai NR, Mosenzon O, McGuire DK, Ray KK, Leiter LA, Raz I, SAVOR-TIMI 53 Steering Committee and Investigators: Saxagliptin and cardiovascular outcomes in patients with type 2 diabetes mellitus. N Engl J Med 2013, 369:1317-1326.
51. Gokce N, Keaney JF Jr, Hunter LM, Watkins MT, Menzoian JO, Vita JA: Risk stratification for postoperative cardiovascular events via noninvasive assessment of endothelial function: a prospective study. Circulation 2002, 105:1567-1572.

52. Gokce N, Keaney JF Jr, Hunter LM, Watkins MT, Nedeljkovic ZS, Menzoian JO, Vita JA: Predictive value of noninvasively determined endothelial dysfunction for long-term cardiovascular events in patients with peripheral vascular disease. J Am Coll Cardiol 2003, 41:1769-1775.

53. Widlansky ME, Gokce N, Keaney JF Jr, Vita JA: The clinical implications of endothelial dysfunction. J Am Coll Cardiol 2003, 42:1149-1160.

54. Corretti MC, Anderson TJ, Benjamin EJ, Celermajer D, Charbonneau F, Creager MA, Deanfield J, Drexler H, Gerhard-Herman M, Herrington D, Vallance $P$, Vita J, Vogel R, International brachial artery reactivity task force: Guidelines for the ultrasound assessment of endothelial-dependent flow-mediated vasodilation of the brachial artery: a report of the international brachial artery reactivity task force. J Am Coll Cardiol 2002, 39:257-265.

55. Thijssen DH, Black MA, Pyke KE, Padilla J, Atkinson G, Harris RA, Parker B, Widlansky ME, Tschakovsky ME, Green DJ: Assessment of flow-mediated dilation in humans: a methodological and physiological guideline. Am J Physiol Heart Circ Physiol 2011, 300:H2-H12.

56. Hausenloy DJ, Whittington HJ, Wynne AM, Begum SS, Theodorou L, Riksen N, Mocanu MM, Yellon DM: Dipeptidyl peptidase-4 inhibitors and GLP-1 reduce myocardial infarct size in a glucose-dependent manner. Cardiovasc Diabetol 2013, 12:154.

57. Hu G, Zhang Y, Jiang H, Hu X: Exendin-4 attenuates myocardial ischemia and reperfusion injury by inhibiting high mobility group box 1 protein expression. Cardiol J 2013, 20:600-604.

58. Liberati A, Altman DG, Tetzlaff J, Mulrow C, Gøtzsche PC, loannidis JP, Clarke M, Devereaux PJ, Kleijnen J, Moher D: The PRISMA statement for reporting systematic reviews and meta-analyses of studies that evaluate healthcare interventions: explanation and elaboration. BMJ 2009, 339:b2700.

doi:10.1186/1475-2840-13-21

Cite this article as: Oyama et al:: Do incretins improve endothelial function? Cardiovascular Diabetology 2014 13:21.

\section{Submit your next manuscript to BioMed Central and take full advantage of:}

- Convenient online submission

- Thorough peer review

- No space constraints or color figure charges

- Immediate publication on acceptance

- Inclusion in PubMed, CAS, Scopus and Google Scholar

- Research which is freely available for redistribution 